UDC 631.53.01

(C) 2016

O. Ivashchenko, Academician of the NAAS, Doctor of Agricultural Sciences Institute of Bioenergetic Cultures and Sugar Beet NAAS

O. Ivaschenko, Doctor of Agricultural Sciences Institute of Plant Protection, NAAS

\title{
BIOLOGIZATION OF AGRARIAN PRODUCTION
}

The purpose. To develop the updated methods of importation of pesticides. Methods. Simulation of natural processes of interaction of plants and metabolism. Results. Development of more perfect methods of coating specimens on target plants will enable not only in ten times decrease chemical load on landscape, but also to ensure reliable crop protection, in particular at intensive techniques of growing. Conclusions. The future farming agriculture potentially is capable to bridge harmonically high biological efficiency of sowings to use of intensive techniques and ecological acceptability of their use.

Key words: intensive techniques, productivity, contamination, bionomics, protection of plants.

Since the formation of agriculture, people have always wanted to receive from the units of arable land the maximum crop of crops they have grown. Such a desire was universal, from the territory of the Trypillya culture, to the ancient Sumer in the south of modern Iraq. In order to achieve its goal, the farmer worked hard, generalized previous experience, engaged in plant breeding, experimented with agro-measures and built logical systems in corresponding technologies of growing crops of specific crops. Condensed and generalized experience of thousands of years of work on the ground is now realized in the derived objective laws of agronomy, logical systems of agriculture, developed branches of agrarian science [1]. The second half of the twentieth and the beginning of the twenty-first century. - a period of wide introduction of intensive modern technologies for the cultivation of almost all agricultural crops [2]. Such an approach to agricultural production has its own logic. On 
each hectare of arable land productivity has increased substantially, which is manifested not only in specific volumes of gross collections of grain, seeds, root crops, tubers, etc., but also economically feasible and profitable [3]. It seems we are on the right track and it remains only to continue moving in this direction. However, besides undeniable successes in modern intensive agriculture, there are significant undesirable components. The countries that were the first to take intensive agrarian production and have achieved the greatest and undeniable success are now initiators of reviewing their own approaches to solving the problem. For example, the Netherlands, the country with the most intensive agricultural production in Europe, is currently one of the initiators of new environmental approaches to work on the ground [4]. The well-known motto: "What is not ecological, that is not economical" is now launching its realization in life [5]. The practice of applying and maintaining intensive technologies for growing agricultural crops is prompted by the need to find new scientific approaches to agrarian production.

It is clear and natural that there is a desire to receive large gross collections of agrarian products each year. For this purpose, the efforts of domestic breeders created and create new modern high-quality varieties and hybrids that are capable of forming under favorable conditions of vegetation: wheat grains - 10-13 t / ha, corn - 14-17, sunflower seeds - 5-6, soybean seeds - 4-5 $\mathrm{t} / \mathrm{ha}$, etc. [6]. However, the implementation of such productive potential of varieties and hybrids of agricultural crops requires appropriate conditions on arable land, first of all, a high level of soil fertility and sufficient moisture reserves that would ensure the formation of plants with the required amount of organic matter [7]. For example, the formation of 1 ton of wheat winter wheat is a prerequisite for the assimilation of plants in the average compounds of nitrogen - $35 \mathrm{~kg}$, phosphorus - 13.5 and potassium - $26 \mathrm{~kg}$ [8]. If you plan 12 tons of grain per hectare of crops, then the removal of mineral nutrition from 
plant crops should be increased by 12 times and totaled $894 \mathrm{~kg}$ of active substances (a.s.) Per hectare. However, it is only a plant outlet. According to the coefficients of plant cultivation in the first year after the introduction of mineral fertilizers (they are the highest in this period), the soil should contain substantially more organogenic substances, at least $1794 \mathrm{~kg}$ d.r. per 1 hectare Dear reader may object. In the calculations of mineral resources, only mineral fertilizers are taken into account, and a significant part of the necessary substances of the plant is removed from the arable soil layer. It is so. However, all these figures must be compensated for by the previous introduction of the corresponding volumes of organic and mineral fertilizers. Otherwise, there is a contradiction with the effect of the objective law of "return", and in subsequent years the level of soil fertility will be guaranteed to decrease [9]. At first glance, there is no problem: we will make more fertilizer (first of all, the most convenient in practice - mineral) and we will solve all these problems. The practice of such an approach itself was not justified primarily by the environmental assessment. A large number of organogenic substances are compounds of nitrogen, which, in the presence of moisture in the soil, are easily translated beyond the boundaries of the arable layer in the groundwater [10]. There is an eutrophic "flowering" of reservoirs with all undesirable ecological consequences. Subterranean waters, in particular aquifers, are used to supply the population with drinking water [11]. The sad ecological assessment of the Dutch experience confirms such negative side effects of agricultural production in- ventation. As a result, in this country, at the legislative level, the maximum level of application of fertilizers on arable land is reduced from the traditional 660 to $520 \mathrm{~kg}$ a.s. [12]. If the application of high standards for the introduction of organogenic compounds creates environmental problems, then compensate for the significant volumes they need to form large gross agricultural product collections. Agrophytocenoses in the condition of mineral nutrition deficiency do not show high biological 
productivity [13]. The practice of widespread introduction of intensive technologies for growing crops of agricultural crops by the most convenient technocratic method conducts agrarian production in a deadlock of contradictions with nature. The higher the intensity of the cultivation technologies, the more ecological problems the farmer generates on arable land. Such problems call into question the possibility of a person's healthy existence [14]. It is logical to estimate the problem in another plane. Is it possible to combine intensive cultivation technologies with a high level of environmental safety? What do you need? Let's try to methodologically outline the range of problem parameters that require a positive solution. First of all, we need to ensure that the very nature can compensate for the negative destabilizing effect on the environment that the farmer forms on arable land with intensive production technologies. The practice of the advanced countries of the world proves that 1 hectare of arable land requires at least 2 hectares of natural or cultivated pastures with a solid vegetation throughout the year. They must be filled with forest vegetation covering not less than 20 $30 \%$ of the territory. Accordingly, in the structure of the territory, the arable land should be on average about 20-30\% [15]. For example, in the United States, the level of cultivation of the territory is $12 \%$, in the Common Market countries it is $25.6 \%$, in Ukraine $-56.7 \%$, the level of afforestation of the territory is about $16 \%$ [16]. The structure of the territory and its use directly affect the intensity of erosion processes on arable land.

In our country, erosive processes affect $80 \%$ of the area of arable land. Technocratic consumer perception of arable land as areas and substrate for agricultural production using intensive cultivation technologies leads to ecological problems. An alternative to a significant presence of organogenic substances in the arable layer may be the full promotion of the biological activity of the soil microflora, which maintains existing organogenic 
compounds in an easily bonded state and constant biological cycle [17]. In order to provide such favorable conditions of existence, they need a balanced level of soil acidity, optimal moisture and the presence of a sufficient amount of organic compounds of carbon in the form of organic substances containing energy-retained in chemical bonds. The level of biological activity of the microflora of the arable land is significantly influenced by the intensity of the application of various groups of pesticides [18]. Some of them have high persistence rates and have a negative impact even after a year or more after applying them. Intensive technologies traditionally provide for widespread use of pesticides for reliable protection of crops. For example, for the protection of intensive gardens and vineyards from a complex of pests and diseases, 15-25 or more spraying with fungicides and insecticides is practiced for the season [19].

Seeds of beet sugar must be sprayed with herbicides 3-5 times. Modern highproductivity agriculture can not be abandoned by using pesticides because of the real threat of reducing the productivity of most agricultural crops by at least $40 \%$ or more [20]. The question is: is it possible to reduce the level of chemical pesticide loading on arable land if their use is mandatory? Objective analysis of the situation makes it possible to say positively. First of all, the mass use of pesticides in industrial practice is carried out when the scientific forecast does not accurately take into account the biological peculiarities of diseases and pests. An important reserve for reducing the chemical load on the environment may be the improvement of the methods of applying pesticides to the target plants of the plant [21]. In addition to seeding, fumigation, the most common method of application is spraying. Improving the spraying method (changing nozzle designs, drop sizes, etc.) can only partially improve the situation. It is possible to improve the uniformity of application of droplets on plants, but the spraying method does not allow to reduce 
unproductive losses of the working fluid during the process of such a technological operation. The studies of the distribution of working fluid on crops during spraying prove that such losses are very high. For example, during the spraying of beet seeds with sugar insecticides from a large number of beet pulp (more than 4 beetles per $1 \mathrm{~m} 2$ sowing), only $0.02 \%$ of the working fluid flow rate falls on the plant's culture, and $99.98 \%$ of the preparation is applied to the soil, that is there is pollution in the environment. Spraying sugar beet crops to protect them from weeds in the phase of developed cotyledons in plant plants (stairs of weeds are the most sensitive to the action of drugs in the phase of cotyledal - 2 leaves) provides for application to plants (sugar beet and boar 'i-n) on average $1-3 \%$ of the rate of introduction of the working fluid. Accordingly, $97-99 \%$ of the volume of working fluid with drugs comes to the surface of the soil, that is, direct losses that only pollute the environment. The development of improved methods of applying drugs to target objects - plants will not only reduce the chemical burden of the environment to dozens of times, but also provide reliable protection of crops, in particular, for intensive cultivation technologies. However, this is not all the problems of using intensive technologies. More and more actual is the problem of overpopulation of the arable layer and the basis of heavy equipment. Modern agrarian production is deliberately aimed at the use of modern wide-reaching aggregates on arable land. These are modern soil-cultivating complexes, with high productivity, reliable and easy to operate. At first glance, everything is fine, except for a little trifle. The specific pressure of such powerful aggregates is traditionally very high and often reaches $1.6 \mathrm{~kg} / \mathrm{cm}^{2}$ (for reference: the permissible specific pressure on the soil of arable land must not exceed $0.6 \mathrm{~kg} / \mathrm{cm}^{2}$ ). One can deny, but what width of capture, what is the productivity of each such unit? The above indicators are really great. However, to what depth will the spring and spring be deformed and deformed arable layer and substrate, and how many years 
is it necessary for the soil in the rut of such an aggregate to return to its natural density? Changes in soil density indicators have traditionally negatively affected the growth and development of crop plants (for comparison, the increase in soil density from 1.20 to $1.34 \mathrm{~g} / \mathrm{cm}^{3}$ leads to a reduction in the yield of corn crops by almost $40 \%$ ). The total area of the tracks leaving the soil tillage units on the field during the vegetation period is often more than half the area of the field itself. That is, the effect of reclosure on agricultural plants in crops is significant. Accordingly, measures that will ensure a reduction in the level of redevelopment of soil on arable land are relevant. Achieving the desired reduction is possible by increasing the area of the wheels or the use of a modern crawler for performing field operations. The given list of problems that form intensive cultivation technologies on arable land is far from complete. It can be substantially supplemented taking into account the specifics of the regions, the features of the relief and soils, a set of crops that are prioritized for cultivation. The problems presented in the review are weighty, but it is quite possible to solve them positively in full or substantially reduce their severity and increase the level of environmental safety of intensive technologies for growing crops. A powerful domestic agricultural science, first of all NAAS, can be on a par with the tasks that it faces and agrarian production. Environmental problems are not delayed. Late with the constructive technological solution of environmental problems induced by intensive technologies of growing crops of agricultural crops, leads to arable land and entire regions of the country to severe social and economic consequences. We have to overcome them and provide agricultural production with the prospect of a stable and long-term development on a rich, healthy and fertile land. 


\section{Conclusions}

Future agriculture can potentially harmoniously combine the high biological productivity of crops with the use of intensive technologies and the ecological acceptability of their application. High productivity of agricultural crops for intensive cultivation technologies should be based, first of all, not on the creation of significant free reserves of organogenic elements in the arable layer, but on the formation of high biological activity of the microflora of the soil and a sufficient amount of readily accessible binding forms of organogenic compounds that does not allow them to translocation from the arable layer. Increasing the environmental quality of the systems for protecting crops from harmful organisms in intensive cultivation technologies is possible thanks to the scientific improvement of the systems for forecasting the stages of their development and the development of new systems for the purposeful application of the working fluid with preparations for plants only, without simultaneous contamination of non-target objects. Modern agricultural machinery complexes must meet the requirements of preserving the health and fertility of soils and do not exceed the specific pressure on the soil above the index of $0.6 \mathrm{~kg} / \mathrm{cm}^{2}$.

\section{Bibliography}

1. Science, governance and environmental impacts of mines in developing countries: lessons from Ok Tedi in Papua New Guinea/R.Q Grafton \& K. Hussey, eds//Water Reseurces Planning and Management. — Cambrige University Press, 2011. - P. 583 - 597.

2. Zemlerobstvo KhKhl stolittya - problemy i shlyakhy vyrishennya; za red. V.F. Kamins'koho. - K.: VP «Edel'veys», 2015. - 269 s.3. Abu Hamad\&Borresen $T$. Socioeconomic factors affecting farmerspercepcions of land degradation and stonewall terraces in central Palestine. Environ Manage, 2006. - 37. - P. $380-394$. 
4. Planetary boundaries: Guiding human development on a changing planet/ W. Stefen, K. Rechardson, S.E. Cornell et al.//Sciece. - 2015. —№1. - 10 p.

5. Kibbewhite M.G. Soil healith in agricultural systems/M.G. Kibbewhite, K. Ritz, M.J. Swift//Phil. Trans Royal Soc, 2008. - 363. - P. 685 - 701.

6. Бегей С.В. Екологічне землеробство: підручник/С.В. Бегей, І.А. Шувар. - Львів: Новий Світ, 2000. - 428 с.

7. Zhuchenko A.A. Adaptyvnaya stratehyya ustoychyvoho razvytyya sel'skoho khozyaystva Rossyy v KhKhl st. Teoryya y praktyka: v. 2 t./A.A. Zhuchenko.

- M.: Ahrorus, 2009 - 2011. - T. 2. - 624 s.

8. Myneev V.H. Khymyzatsyya zemledelyya y pryrodnaya sreda/V.H. Myneev.

- M.: V.O. «Ahropromyzdat», 1990. - $286 \mathrm{~s}$.

9. Sayko V.F. Zemlerobstvo v konteksti zmin klimatu/V.F. Sayko//Zb. nauk. prats' NNTs «IZ NAAN». - K.: EKMO, 2008. - R. 3 - 14.10. Furusaka C. Global environment and microorganisms/C. Furusaka//Bull. Jpn. Soc. Microb. Ecol., 1993. - 8(2). - P. 127 - 131.

11. Sollins $P$. Stabilization and destabilization and of soil organic matter: mechanisms and controls/P. Sollins, P. Homann, B.A. Caldwell//Geoderma. - 1996. - 74. - P. $65-105$.

12. Yakushev V.P. Na puty k tochnomu zemledelyyu/V.P. Yakushev. - SPb.: Yzd-vo PYYaF RAN, 2002. - 458 s.

13. Yaroshko M. Derzhavne rehulyuvannya sivozmin/M. Yaroshko//Propozytsiya. - 2013. - № 8. - S. 26 - 27.

14. Pervushyn A. Upravlenye klymatom - blaho yly bezdeystvye/A. Pervushyn//Sekretnыe materyalы. - 2010. — \# 23 (301).

15. Sayko V.F. Sivozminy v zemlerobstvi Ukrayiny/V.F. Sayko, P.I. Boyko. K.: Ahrar. nauka, 2002. - 145 s.

16. Tararyko A.H. Ahroэkolohycheskye osnovы pochvozashchytnoho zemledelyya/A.H. Tararyko. - K.: Urozhay, 1990. - 182 s.17. Crossley D.A. 
Biodiversity of Microarthropods in agricultural soils: relations to processes/D.A. Crossley, B.R. Mueleer, J.C. Perdue//Agric. Ecosist. Environ, 1992. - 40. - P. $37-46$.

18. Fedtke K. Byokhymyya y fyzyolohyya deystvyya herbytsydov/K. Fedtke.

- M.: Ahropromyzdat, 1985. - $222 \mathrm{~s}$.

19. Lunev M.Y. Pestytsydb y okhrana ahrofytotsenozov/M.Y. Lunev. - M.:

Kolos, 1992. - $269 \mathrm{~s}$.

20. Intehrovanyy zakhyst roslyn na pochatku KhKhl st./Materialy mizhnar. nauk.-prakt. konf. - Kyyiv, 1 - 5 zhovtnya 2004 r. - K.: Kolobih, 2004. $771 \mathrm{~s}$.

21. Ivashchenko O.O. Maybutnye systemy zakhystu roslyn, ekolohichni aspekty/O.O. Ivashchenko, O.O. Ivashchenko//Karantyn i zakhyst roslyn. 2015. - № 9. - S. 1 - 4. 